\title{
'n Redaksionele voorwoord tot die Hervormde Teologiese Studies se Goue Jubileum
}

\author{
A G van Aarde \\ Redakteur
}

Die vyftigste jaargang word met die onderhawige aflewering van die Henormde Teologiese Studies ( $=$ HTS) betree. HTS is die vaktydskrif van die Fakulteit Teologie (Afdeling A) aan die Universiteit van Pretoria en is die oudste bestaande teologiese vaktydskrif in Suid-Afrika. Terselfdertyd word $H T S$ deur die Hervormde Teologiese Vereniging as die vereniging se vaktydskrif ondersteun. Die redaksie, wat bestaan uit die lede van die teologiese fakulteit, is dankbaar vir die voorreg om die tydskrif se goue jubileum te kan vier. Die welkomswoorde van ds T F J Dreyer, die destydse skriba van die Kommissie van die Algemene Kerkvergadering van die Nederduitsch Hervormde Kerk van Afrika, in die eerste aflewering vyftig jaargange gelede, is sprekend van 'n besondere verbintenis. Die Hervormde Teologiese Studies en die Fakulteit Teologie (Afdeling A) aan die Universiteit van Pretoria is naamlik onlosmaaklik aan die Nederduitsch Hervormde Kerk van Afrika verbonde. Dit is daarom gepas dat die huidige voorsitter van die Kommissie van die Algemene Kerkvergadering, dr D J C van Wyk, by HTS se vyftigste verjaardag ook 'n voorwoord geskryf het. Die redaksie neem met dankbaarheid kennis van dr Van Wyk se gelukwensing daarin en sal ook die nodige aandag gee aan sy kritiese refleksie. Dr van Wyk is 'n baie lojale vriend van $H T S$ en het self al twintig navorsingsartikels in $H T S$ laat publiseer. Hierdie prestasie is prysenswaardig en kan van geeneen van die ander medewerkers gesê word wat nie voltydse hoogleraars aan die teologiese fakulteit was en is nie. Prof dr A D Pont, emeritus-professor in Kerkgeskiedenis en Kerkreg, is versoek om 'n historiese oorsig van die vyftigjarige bestaan van HTS te skryf. Dit is baie gepas dat dit juis prof Pont is wat hierdie oorsig saamgestel het. Hy is nie net 'n geëerde oud-redaksielid nie, maar was self vanaf 1957 tot 1971 verantwoordelik vir die versorging van die tydskrif en het ook vanaf 1982 tot 1985 as redaksiesekretaris opgetree. Hierbenewens is prof Pont dié medewerker wat verreweg die meeste artikels in HTS laat publiseer het, te wete ses en sestig tot en met Jaargang 49/4 (1993). Die redaksie rig hiermee 'n woord van hartlike dank aan prof Pont vir sy toewyding en lojaliteit.

Sowel dr Van Wyk in sy voorwoord as prof Pont in sy oorsig maak melding van die doelstellings wat die redaksie van $H T S$ vyftig jaargange gelede gestel het en van die feit dat daar op die titelblad vermeld is dat Henvormde Teologiese Studies ten doel het die bevordering van die Bybels-Reformatoriese teologie in Suid-Afrika. Dr van Wyk spreek in sy voorwoord kritiek uit dat hierdie doelstelling nie meer op die 
titelblad vermeld word nie en vra na die redes wat daarvoor kan bestaan. Die verandering van die titelbald het met Jaargang $32 / 3$ \& 4 (1976) ingetree, maar dit is onseker waarom dit gebeur het. Die betrokke aflewering het as subtitel ' $B \mathrm{~J}$ Engelbrecht Jubileumnommer'. Dié aflewering het gedien as herdenking van prof dr B J Engelbrecht se vyf en twintigjarige hoogleraarskap.

Vanweë hulle roeping en verbondenheid aan die Nederduitsch Hervormde Kerk is al die lede van die huidige redaksie en ook die redakteur uit innerlike oortuiging, steeds soos die eerste redaksie, verbind tot die bevordering van die Bybels-Reformatoriese teologie. Die redakteur het die afgelope tien jaar en meer van diens as publikasiesekretaris en as redakteur, met die goedkeuring van die hele redaksie en soos dit die gebruik was sedert die eerste jaargang, ruimte gebied vir wetenskaplikes vanuit die kringe van teologiese tradisies buite die Nederduitsch Hervormde Kerk van Afrika om akademiese bydraes in HTS te laat publiseer. Met die verskyning van Jaargang 41 (1985) tot en met die verskyning van hierdie jubileumnommer as Jaargang 50 (1994) het die redakteur op die titelblad daarop gewys dat hy met die hulp van ander vakkundiges alle bydraes formeel en inhoudelik keur en dat die redaksielede hulle nie noodwendig met die menings van medewerkers vereenselwig nie. Die redakteur is nie daarvan bewus dat die Bybels-Reformatoriese teologie die afgelope tien jaar in HTS bevraagteken is nie. Buitendien, sowel kritiese ondersoek as selfkritiek is kenmerkend van die Bybels-Reformatoriese tradisie. In onderskeidelik Junie en Augustus 1988 het die redaksie en die beheerraad van die Tydskrifafdeling van die Nederduitsch Hervormde Kerk van Afrika op inisiatief van die redakteur 'n redaksionele beleid goedgekeur. Hierdie redaksionele beleid is in HTS 45/1 (1989), bl 1.2 gepubliseer. Daarin word onder andere die volgende gestel:

Die HTS stel hom ten doel om, in ooreenstemming met sy stigtingsakte (kyk [Gemser, B] \& Dreyer, T F J 1943, Woord vooraf en Welkomswoorde, HTS 1/1, 1-3), op nasionale gebied diens te lewer deur die teologiese wetenskap te bevorder, 'n eie Suid-Afrikaanse teologie uit te bou en om sodoende uitvoering te gee aan die opdrag van die Nederduitsch Hervormde Kerk van Afrika aan sy dosente in die teologie om in die kerk leiding te gee in die teologiese arbeid ter wille van die verkondiging van die evangelie. Vir dié doel word bydraes op die gebied van die teologie en aanverwante wetenskappe ook van buite die kring van die Fakulteit Teologie (Afdeling A) aan die Universiteit van Pretoria en die kring van die Nederduitsch Hervormde Kerk van Afrika geinisieer en ontvang. 
Die redakteur vertrou dat daar aan hierdie doelstelling getrou gebly is en dat dit ook met betrekking tot al die navorsingsartikels wat in die onderhawige goue jubileumnommer opgeneem is, waar is. Wat die jubileumnommer self betref, lewer al die lede van die huidige redaksie bydraes (in totaal twaalf) vanuit hulle onderskeie vakgebiede. Hierbenewens is 'n ongepubliseerde studiestuk van wyle prof dr A van Selms oor die hermeneutiek vir publikasie deur dr P B Boshoff voorberei. Prof van Selms was vir vyftien jaar lid van die redaksie en is tot en met Jaargang 49/4 (1993) die medewerker wat die sesde meeste navorsingsartikels (boekbesprekings uitgesluit) in HTS laat publiseer het, te wete ses en twintig. Drie emeriti-professore en oud-lede van die redaksie het ook bydraes vir die goue jubileumnommer gelewer. Prof $\mathrm{F} \mathbf{J}$ van Zyl, emeritus-professor in Godsdiens- en Sendingwetenskap is reeds sedert die eerste jaargang tot en met die verskyning van die nege en veertigste jaargang vir een en twintig navorsingsartikels in HTS verantwoordelik. Sy bydrae in hierdie feesnommmer, so kenmerkend van prof Van Zyl, handel oor die sondebegrip by Karl Barth. Prof J P Oberholzer, emeritusprofessor in die Ou-Testamentiese Wetenskap, se bydrae is een van die referate wat in 1992 gelewer was by geleentheid van 'n fakulteitsimposium ter herdenking van die vyf en sewentigste bestaan van die Fakulteit Teologie (Afdeling A) aan die Universiteit van Pretoria. Prof Oberholzer was vir veertien jaar, sedert sy benoeming as teologiese dosent in 1971, verantwoordelik vir die redaksionele versorging van $H T S$. Afgesien van sy bydrae in hierdie jubileumnommer, het prof Oberholzer reeds ses en dertig ander navorsingsartikels in HTS laat publiseer. Dit maak van hom die vierde mees aktiewe medewerker. Prof A D Pont se voordrag by die fakulteitsimposium in 1992 is ook in die jubileumnommer opgeneem. Dit sal die sewe en sestigste artikel (boekbesprekings uitgesluit) van prof Pont wees wat in HTS gepubliseer is. Die ander referate wat by die gemelde fakulteitsimposium gelewer was, word ook in die onderhawige nommer opgeneem. Dit is die bydraes van proff F E Deist en E Brown (Universiteit van Stellenbosch) en dr H Balzer (vroeër verbonde aan die Lutherse Teologiese Seminarie in Arcadia, Pretoria, en nou lidmaat van die Nederduitsch Hervormde Kerk). Hierbenewens verskyn daar ook 'n artikel van prof L F Schulze van die Potchefstroomse Universiteit vir Christelike Hoër Onderwys. Prof Schulze is 'n ou vriend en gereelde medewerker van die Hervormde Teologiese Studies. Die dekane van vyf teologiese fakulteite in SuidAfrika het op die redakteur se versoek bydraes tot die goue jubileum gelewer. Hulle is, naas die artikel van prof $J \mathbf{H}$ Koekemoer, dekaan van die Fakulteit Teologie (Afdeling A) aan die Universiteit van Pretoria en huidige voorsitter van die redaksie van $H T S$, dié van proff J J Burden (Universiteit van Suid-Afrika), P C 
Potgieter (Fakulteit Teologie, Universiteit van die Oranje-Vrystaat), W S Prinsloo (Fakulteit Teologie, Afdeling B, Universiteit van Pretoria) en H J B Combrink (Universiteit van Stellenbosch). Die redaksie is dankbaar vir hierdie bydraes van buite die eie kerklike kring.

Gedurende die afgelope vyf jaar, vanaf Jaargang 44/1 (1988) tot en met Jaargang 49/4 (1993), was 111 van die 239 navorsingsartikels (boekbesprekings uitgesonderd) wat in die Hervormde Teologiese Studies gepubliseer is, van Suid-Afrikaanse outeurs buite die kring van die Fakulteit Teologie (Afdeling A) aan die Universiteit van Pretoria afkomstig. Lidmate van die Nederduitsch Hervormde Kerk was vir 113 navorsingsartikels verantwoordelik. Buitelandse outeurs het 15 bydraes gelewer. Van hierdie 239 navorsingsartikels het 173 bydraes in Afrikaans verskyn, 57 in Engels, 5 in Duits en 4 in Nederlands. Wat die navorsingsartikels betref wat die afgelope vyf jaar tot en met 1993 direk deur lede van die redaksie geskryf is en derhalwe vanuit die kring van die Fakulteit Teologie (Afdeling A) self kom, het die Departement Nuwe-Testamentiese Wetenskap 32 gelewer, die Departement Ou-Testamentiese Wetenskap 22, die Departement Kerkgeskiedenis en Kerkreg 18, die Departement Godsdiens- en Sendingwetenskap 15, die Departement Dogmatiek en Christelike Etiek 15, die Sentrum vir Voortgesette Teologiese Toerusting 7 en die Departement Praktiese Teologie 4. Die enigste outeur wat nie 'n lidmaat van die Nederduitsch Hervormde Kerk was nie en gedurende die afgelope vyftig jaargange tot en met 1993 meer as tien bydraes tot die Hervormde Teologiese Studies gelewer het, is wyle prof W S Vorster, in lewe hoof van die Instituut vir Teologiese Navorsing aan die Universiteit van Suid-Afrika. Die lys van outeurs wat die afgelope vyftig jaargange tot en met 1993 tien en meer navorsingsartikels gelewer het, sien soos volg daaruit:

A D Pont -66

$A G$ van Aarde -40

S P Engelbrecht -39

J P Oberhoizer - 36

B J Engelbrecht -32

A van Selms -26

B J Gemser - 25

G M M Pelser - 22

F J van $\mathrm{Zyl}-21$

A S Geyser -20

D J C van Wyk - 20

S J Botha - 19

J H Koekemoer - 19

P J T Koekemoer - 17.
J I de Wet -17

P S Dreyer - 16

P M Venter - 16

$H G$ van der Westhuizen - 15

M J du P Beukes - 15

J J Engelbrecht - 13

A P B Breytenbach 13

P J van der Merwe - 12

W S Vorster - 12

T F J Dreyer - 11

G C Velthuizen - 11

Joh Dreyer - 10

J A Loader - 10 
Die status wat die Henormde Teologiese Studies sedert 1943 verwerf het op die gebied van wetenskaplike teologie, is bepaal deur die kwaliteit van die navorsingsuitsette van bogenoemde medewerkers. Die redaksie wil ook sy dank betuig aan die Universiteit van Pretoria, die Buro vir Wetenskaplike Publikasies by die Stigting vir Onderwys, Wetenskap en Tegnologie en in die besonder die Raad van Finansies van die Nederduitsch Hervormde Kerk van Afrika vir hulle volgehoue finansiële steun oor baie jare. Die redaksie is in die besonder dankbaar vir die administratiewe hulp wat die Tydskrifafdeling van die Nederduitsch Hervormde Kerk van Afrika verleen het en in die besonder dr D J C van Wyk en dr P J de Beer wat die afgelope tien jaar as direkteure opeenvolgend aan die hoof van die Tydskrifafdeling gestaan het. Die Tydskrifafdeling het die afgelope tien jaar die volgende persone as redaksionele asssistente aangestel en hulle was vir die redakteur van onberekenbare hulp: ds Estelle Schepers, ds Erna Oliver en ds Mariëtte Robhertze, mev Anne Barkhuizen, ds Willem Oliver en ds Daan van Wyk (jr). Hierdie goue jubileumnommer is met die ondersteuning van ds D J C van Wyk (jr) en dr E van Eck redaksioneel versorg. Die redaksie is vir hulle tyd en hulp opreg dankbaar. Die nasê van die dankseggingswoord wat die apostel Paulus aan die Tessalonisense gerig het, is miskien gepas:

Ons dank God altyd vir julle almal wanneer ons in ons gebede aan julle dink. Sonder ophou bring ons dan voor God ons Vader in herinnering die werk van julle geloof, die inspanning van julle liefde en die volharding van julle hoop op ons Here Jesus Christus.

(1 Tess 1:2-3) 